\title{
Стенд для исследования параметров фотоприемника ФУР 160 при воздействии лазерного излучения
}

В.В. Карпов, М.Е. Козырев, Н.С. Кузнецов, А.В. Марущенко, В.И. Петренко, Е.В. Сусов, А.В. Филатов

Акционерное общество «Московский завод «САПФИР», Москва, 117545, Днепропетровский проезд, 4A, стр. 3А

тел: +7 (495) 312-02-03, факс: +7 (495) 312-00-55, эл. почта: info@ mzsapphir.ru

DOI 10.34077/RCSP2019-118

В статье приводятся результаты создания стенда для исследования параметров многоэлементного фотоприемника (ФП) ФУР 160 [1] в условиях воздействия лазерного излучения на длине волны 10,6 мкм.

ФП охлаждается при помощи двухступенчатого термоэлектрического охладителя (ТЭО) до температуры порядка минус $45^{\circ} \mathrm{C}$, фоточувствительный элемент фотоприемника выполнен в топологии пятиразрядного кода Грея из ГЭС ІСРТ МЛЭ с шириной чувствительной площадки 0,5 мм.

Характеристики фотоприемника:

- спектральный диапазон чувствительности - 2,0-11,5 мкм;

- размер фоточувствительной зоны - 6х12 мм;

- количество линеек -10;

- количество элементов - 36;

- отношение сигнала к шуму на выходе ФП при минимальной облученности $10^{-8}$ Дж/см ${ }^{2}$ во всех условиях эксплуатации - не менее 4,5;

- максимальная рабочая облученность - не менее $10^{-4}$ Дж/см²;

- разброс сигналов по площадкам фоточувствительного элемента - не более 15 \%;

- максимальная потребляемая мощность - не более 10 Вт;

- время готовности ФП к работе - не более 120 c;

- темповое сопротивление в НКУ - 0,7-1,6 кОм;

- напряжение питания ТЭО - 6,0 $0,2 \mathrm{~B}$;

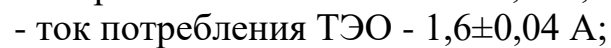

диапазон рабочих температур - минус $50 \div$ плюс $55^{\circ} \mathrm{C}$;

- масса - 43 г.

В процессе комплексных испьгганий опытных образцов ФП был создан стенд, на котором исследовалась работоспособность ФП при максимальной облученности $10^{-4}$ Дж/см ${ }^{2}$ и ширине полосы лазерного излучения 300 мкм на длине волны 10,6 мкм, в том числе измерялось отношение сигнала к шуму на выходе ФП при минимальной облученности $10^{-8}$ Дж/см².

Проведенные на созданном стенде предварительные испытания опытных образцов ФП ФУР 160 позволили признать опытные образцы соответствующими требованиям Т3. По своим характеристикам созданные фотоприемники из гетероэпитаксиальных структур КРТ не имеют отечественных аналогов и по своим параметрам находятся на уровне лучших зарубежных образцов.

\section{Литература}

[1] Гиндин П.Д. и др. Фоторезистор с кодом Грея из гетеро-эпитаксиальных структур КРТ для регистрации импульсного излучения СОг лазера. Труды XXIII Международной научно-технической конференции по фотоэлектронике и приборам ночного видения. - М.: ОАО «НПО «Орион», 2014 г. 